\title{
Creole seeds and power relations in agriculture: Interfaces between Biopower and social agency
}

\author{
Michele Laffayett de Campos \\ Fábio Kessler Dal Soglio
}

${ }^{1}$ Programa de Pós Graduação em Desenvolvimento Rural da Universidade Federal do Rio Grande do Sul, Porto Alegre, RS, Brasil

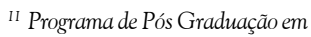
Desenvolvimento Rural da Universidade Federal do Rio Grande do Sul, Porto Alegre, RS, Brasil

\begin{abstract}
The present study deals with the issue of Creole seeds from two approaches: Biopower in Biopolitics by Michel Foucault and Norman Long 's Actor - Oriented Perspective (POA). The objective is to relate the concept of Biopower to the global scenario of appropriation, privatization and commodification of the seeds and to discuss the contributions and fragilities of this theoretical reference, presenting the POA as a complementary approach to support these discussions. This work demonstrated that the application of the two approaches in the study of this thematic, can present novel interpretive and analytical. Experiences of networks of actors that mobilize the conservation of creole seeds, prove the social agency and dynamics against the global dictates. These are experiences that stand in the face of the tax and socio-technical standards processes for the use of commercial seeds and justify the choice of the POA as a complete approach to Biopower.
\end{abstract}

Keywords: Guardians of Creole Seeds; Agroecology; Agrobiodiversity; Sociotechnical standards.

São Paulo. Vol. 23, 2020

Original Article

DOI: http://dx.doi.org/10.1590/1809-4422asoc20180242r2vu2020L5AO 


\section{Introduction}

This paper asks how the theme of Creole seeds has been studied and how approaches involving themes such as tradition, modernity, development, social agency and power relations in agriculture dialogue with the issue of conservation and preservation of Creole seeds. The diversity of approaches to these themes, by different fields of knowledge, citing the contribution and advances of social sciences, present interpretive novelties in addition to the biological, ecological and productive issue of seeds, bringing to light elements that were once relegated to secondary plans of deepening and that today can be understood as fundamental, to highlight the social and organizational relations that permeate the use and conservation of seeds in agriculture and the identity construction of the social actors who maintain these seeds. Farmers who conserve and preserve agrobiodiversity are known in many places as guardians and custodians of Creole varieties. In the Law of Seeds and Seedlings - Law No. 10,711 / 2003, Art. 2, XVI, creole seeds are also designated as seeds of local or traditional variety. These are selected varieties, managed and conserved by family farmers, quilombolas, indigenous people and other traditional peoples, and are permanently being adapted to the forms of management of these populations and their cultivation places. Several approaches have focused on the complexity of the theme of Creole seeds, leaving behind restricted views on this subject, for broader views that understand how much the seeds are immersed in specific contexts and compose a list of social, environmental and political aspects and dimensions in the rural space. Aiming to discuss some of the theoretical and analytical novelties, this essay will deal with the theme of Creole seeds from two approaches: that of Biopower in Biopolitics by Michel Foucault (2008) and that of Norman Long's Actor Oriented Perspective (POA) ( 2007). To enrich the discussion we present the case of the guardians of Seeds of the Passion of Paraíba-PB. In each region and according to the social, cultural and political dynamics that drive its use and conservation, seeds can gain a name - and a symbolic meaning. This meaning can often be linked to farmers' ways of life and be related to the political and identity construction of rural communities. In Paraíba, groups of farmers recognized as guardians, called their creole seeds "Seeds of Passion". This designation was born in the context of mobilizations for the rescue of Creole seeds and rural traditions that were falling out of use, just like the practice of storing Creole seeds. The State of Paraíba is recognized for its success in the experience of Community Seed Banks (BSC) in the scope of Agroecology. Thousands of farming families participate in the Seeds of Passion network. This emblematic experience provides us with subsidies to discuss alternative dynamics in agriculture and new trends that seek to rethink agricultural production and consumption in a more inclusive, economically fair and environmentally sustainable way. In view of the disastrous consequences of the modernization of agriculture, the conservation of biodiversity, agrobiodiversity and Agroecology, manifest themselves as responses to the degrading scenario in the socio-cultural and environmental spheres. The aim of this study is to relate the concept of Biopower in Foucault's Biopolitics to the global scenario of seed appropriation, privatization and commercialization and to discuss the contributions and weaknesses of this theoretical framework, presenting the Actor Oriented Perspective 
as a complementary approach to support these discussions . In addition, some advances obtained with the POA will be presented in studies focused on the strategies and practices of the social actors who exercise the role of guardians of creole seeds and how these actors manage to build other paths against the trends dictated by the global market. of seeds. The article is divided into sections after this Introduction. We started the first section by addressing the issue of Creole seeds, specifically the problem of the appropriation and privatization of agrobiodiversity in conventional agriculture. Then we deal with the concept of Biopower in Foucault's Biopolitics and, later, we entered the discussion about Creole seeds from Biopower. Then, it passes to the guardians of Creole seeds from the Actor Oriented Perspective (POA). The last section discusses the conceptual arrangement between Foucault's Biopower and Norman Long's Actor Oriented Perspective (POA) in the approach to creole seeds. In the end, some considerations are made.

\section{Appropriation and privatization of Agrobiodiversity}

In Brazil, agriculture underwent radical changes in its technological standards and in social relations since the 1960s. The central objective was to transform agriculture into a "great granary" in order to consolidate it as an exporter of agricultural raw materials. With the modernization process, what Graziano Neto (1985) called "industrialization of agriculture" occurred, making it a business activity and inserted in the normalization devices of the market. It is in this market plot, that commercial seeds and chemical inputs started to be evoked as essential inputs to achieve greater productivity and reduce food prices. The "technological packages" refer to a set of techniques and inputs that were introduced in rural areas since the Green Revolution. These packages consist of the use of mechanization in soil preparation, sowing and harvesting; use of commercial hybrid and transgenic seeds; use of fertilizers and chemical fertilizers and irrigation (ALTIERI, 2012). These technologies were produced outside the domain of farmers and disseminated in rural areas via rural extension and technical assistance (NEVES, 2008). Farmers were and still are urged to specialize their production systems. In general, technological packages were created to control the unwanted natural factors and overcome the factors that limited productivity in agriculture, in order to provide the necessary conditions for large-scale production (GOODMAN; SORJ; WILKISON, 2008). After about fifty years of the Green Revolution, its effects on rural areas and on society as a whole remain and continue to emerge. The use of pesticides and commercial seeds has intensified, supporting monocultural practices. The seeds were gradually treated as a commodity, becoming one of the most profitable "arms" in agribusiness. Goodman, Sorj and Wilkinson (2008) use the terms appropriationism and substitutionism to refer to the appropriation of natural elements and processes by industry and the replacement of environmental services, goods or natural resources, such as seeds, by industrial and commercial processes and inputs. . As a result, Creole varieties (landraces) have been gradually replaced by commercial seeds - hybrid seeds and genetically modified seeds (SANTILI, 2009).

The seed is the genetic resource essential to agriculture and the privatization, 
patenting and commercialization processes, usually carried out by large companies, supported by legal systems controlled by them, are the maximum expression of the exercise of control and power structures in agriculture (SHIVA, 2001; 2003). By controlling the seeds, it becomes possible to control other factors of production as well. In this context, serious conflicts involving seeds are happening, gaining proportions, just as it has been with the struggle for land (MONTECINOS, 2014). To exemplify, the legal difficulties for the use and commercialization of Creole seeds, the conflicts involving several punitive sanctions for farmers who do not follow the official rules of the international seed market, the pressure from large companies in conjunction with financial institutions for the use of seeds trade to the detriment of Creole seeds, the exclusion of farmers who do not follow such prescriptions and other situations that even involve armed conflicts and real wars over seeds (MONTECINOS, 2014).

The issues surrounding the theme of Creole seeds, result from a diverse scope of discussions and problematizations in the scientific / academic scope and also in the scope of social organizations and public policies for rural areas. It is notable that the Creole seeds are part of a discursive axis that provides practices that are in favor of the autonomy and food and nutritional sovereignty of farmers, in an agriculture free of pesticides and in opposition to the socio-technical standards of the modernization of agriculture, above all, the use of seeds genetically modified. This discursive axis, for the most part, assumes the ideals of Agroecology, which provides the scientific, methodological and technical bases for ecological, biodiverse and energy efficient and socially fairer production systems (GLIESSMAN, 2008; ALTIERI, 2012 ). These pillars are strongly linked to the notion of food and nutritional security and sovereignty. It is in this meander that some old or traditional practices reappear that are gaining new designs, such as, for example, the social strategies and practices of use and conservation of Creole seeds and the reconstruction of the traditional identity or the construction of an invented tradition of seed guardians Creoles (PAULINO; GOMES, 2015).

\section{Creole Seeds in the context of Agroecology}

Faced with the degrading scenario in conventional agriculture, scholars increasingly reinforce the consequences of modernizing agriculture, exposing concerns and proposals for building sustainable agricultural systems. Agroecology emerges in this context as a possibility for the redesign of agroecosystems. The field of Agroecology deals with threats to agrobiodiversity and discusses opportunities and strategies for its conservation and sustainable use. Genetic diversity is essential not only for the survival of the human species, but also for the ecological processes essential to Agroecology and the maintenance of life on the planet (ALTIERI, 2012). Practices guided by the scientific principles of Agroecology are seeking, with the active participation of farmers themselves and their communities, a variety of purposes, which reflect in the perspective of values such as social justice, participatory democracy and sustainability (GLIESSMAN, 2008). Purposes that include productivity, the sustainability of agro-ecosystems, the protection of biodiversity, food security and the health of their communities, as well as the 
strengthening of their cultures and traditions, agency and well-being (LACEY, 2015). It is observed that within the scope of Agroecology, important initiatives for the use and conservation of agrobiodiversity with family farmers and traditional communities are taking place. When discussing these initiatives, we favor the reflections that contribute to the social practices of rescue, conservation, participatory improvement, use and exchange of local seeds, as well as for the collective elaboration and negotiation of public policies on the subject. In this general context, regarding the issue of seeds, the categories of guardians of creole seeds and their different conservation practices are justified. The opposition of various social actors to the advances in the modernization of agriculture, which in essence disseminates commercial seeds and various inputs correlated to them, in addition to the role of maintainers of genetic resources as a common good, the guardians of Creole seeds, increasingly call attention. Many studies have tried to demonstrate how these guardian farmers resist and are fundamental in the processes of food security and sovereignty, as protagonists in the preservation and conservation of varieties that are disappearing (PEREIRA, 2017). These actors, for a long time, were devalued and their practices overwhelmed by ideologies and practices of conventional agriculture.

\section{Creole Seeds from the perspective of Biopower}

About three decades ago, Foucault's works arouse interest for studies on development, modernity and its dilemmas (RADOMSKY, 2015). It is at this juncture that seeds as an element strongly related to rural development procedures begin to be studied from Biopower. Before addressing the concept of Biopower, it is necessary to explain about three different manifestations of power suggested by Michel Foucault (2007): sovereign power, disciplinary power and biopower. In sovereign power, Foucault reviews classic thinking and identifies how power was conceived and interpreted from sovereignty. It is a technology of power characteristic of absolutist societies that preceded democracy. This technique "absolutized" the sovereign's power over his subjects, conditioning them to serve them. Thus, the sovereign was the one who had absolute power in governing and using terror. An expression usually used to summarize the sovereign's power is that he had the right to "make him die, let him live" (DINIZ; OLIVEIRA, 2013). However, Foucault is not restricted to the analysis of power from the sovereign, as it also focuses on how subjects were gradually constituted. Thus, it is possible to think of power not as a violent and compelling imposition, but as an ideological construct that is massively accentuating certain social classes and identity functions. Analyzing in this way, it is possible to understand how the mechanisms and procedures of power act at the levels of society and then move, expanding to be invested and annexed in "more global phenomena", taking on large proportions (FOUCAULT, 1978). Foucault notes that it is in European societies of the 18th century that other technologies of power emerge (FOUCAULT, 2007). These technologies will only be possible with the advent of the "subject" category in which people's physical bodies are seen as spaces in which new forms of power could be exercised. This occurs with the institutionalization of schools, hospitals, armies and armed forces, police and prisons and other 
environments capable of individualizing the subject and using disciplinary techniques to "domesticate" or "docilize" them. Many techniques of physical and psychological violence were draped with techniques. In biopower, the techniques go through dimensions and narratives wrapped up in the search for freedom, inclusion, development and well-being. In the plots of biopower, freedom, inclusion and development become the basis of a discourse surrounded by political and economic interests. Development gains prominence, as a connection apparatus in which it is possible to glimpse the overcoming of "underdeveloped" conditions. Issues involving misery and poverty, food scarcity, world agricultural production, disease eradication, literacy and technical training, among other issues essential to developmentalism, are on the agenda (RADOMSKY, 2015).Based on Foucault's theoretical framework, it can be argued that seeds are inserted in the rationality of "making people live, letting die" in biopolitics. The control of the means of production and food by the global market, determines who can and who cannot eat in the world, as Shiva $(2001,2003)$ highlights in his works. Examples of this are the decrees, laws and parliamentary measures that suspend articles of the constitution, allowing the elimination of life, not only from political opponents, but from entire categories of citizens, such as indigenous peoples, blacks and farmers. Therefore, it is decided on the point at which life can become politically and legally irrelevant, and in this sense, without value (ARÁN; PEIXOTO, 2007).

From there, a permanent state of emergency is created, which has become common practice in democratic states. For Agamben (2004), it is a state of exception, making it possible to annul the individual's legal status, creating a legally unnameable being, which does not fit the guidelines of modernity and development, being left out, at the mercy. To exemplify this context in the context of seeds, we can mention the criminalization of farmers who reserve and store part of their crops to reproduce in an upcoming planting or for consumption and commercialization (MONTECINO, 2014). We can also mention the obstacles that result in the exclusion of agricultural credit programs and lines for those farmers who use their Creole seeds and who do not fit into the prevailing socio-technical regime.

In the name of modernity and development, laws are suspended and a state of terror is established. Farmers who do agriculture, under the aegis of their exercise, live the limit experience and the suppression of their dignities, identities, social practices and traditions. Increasingly, the proclamation of the state of exception is now being envisaged as a measure of security, hygiene and sanity, defending democracy, science and knowledge.

In this context, the state of the law, in which the law of farmers' rights to agrobiodiversity and among other laws, are in force, are immersed in socio-technical devices that weaken them (SANTILI, 2009). In other words, the laws that guarantee the rights of farmers to agrobiodiversity are not applied, whereas the laws that guarantee certification devices, the privatization of seeds, the appropriation of farmers' products, the bureaucratization of agricultural work, actions violent acts such as inspection, repression and seizures are relentless and increasingly strengthened (PFRIMER; DE FREITAS COCA; JÚNIOR, 2016). Radomsky (2015) in his study shows that the issue of seeds is central to 
agriculture. The issue of seeds denounces the disarticulation and violence that spheres of the State and private institutions carry out. The author observed that rural credit systems have catalogs of seeds recommended for planting, generated in an agricultural system that includes other products for the production of these seeds, such as pesticides, but also a series of practices and management that are only possible in a conventional and monocultural based agriculture. It is necessary to realize that with regard to seeds and their selectivity, the norms become sociotechnical constraints and pressures and affect the lives of farmers with great impact (RADOMSKY, 2015).

\section{Actor Oriented Perspective (POA)}

The Actor Oriented Perspective (POA) is a post-structuralist and constructivist approach, formulated by Norman Long and Jan Douwe Van der Ploeg, linked to Wageningen University, in the Netherlands. In general, these researchers question the theories based on structuralism, such as the Modernization Theory and some aspects based on the Marxist Theory. According to Long and Ploeg $(1994,2011)$ and Long (2007) these theories converge when interpreting development and social change as a production of external agents, dependent on state, private, non-governmental national and international institutions.

The analysis of the social process from an Actor Oriented Perspective tends to avoid the determinism of general theories, seeking to question the different ways and strategies that social groups create to face changes, adversities and power games and impositions. Therefore, it seeks to allocate the analysis lens based on the understanding of the actors' actions, of the social agency and, it tries to reach the heterogeneity of the social action and practice (COTRIM; DAL SOGLIO, 2010).

POA emerges as a differential for development studies, providing theoretical and methodological foundations from the actor and social construction (GONZÁLEZ; PEREIRA; DAL SOGLIO, 2014). The advantage of working with an actor-centered approach is the possibility of perceiving different responses in apparently homogeneous processes and immersed in power relations. These different responses can be interpreted and discussed by taking into account the fact that social actors are not passive recipients of interventions, but active participants, endowed with the capacity to reflect and create strategies through their social and institutional interactions (LONG, 2007).

Thus, it is possible to understand the processes that culminate in the construction of social development projects and how the different actors act in this construction (GONZÁLEZ; PEREIRA; DAL SOGLIO, 2014). The notion of agency attributes to actors, according to Long (2007), the ability to process social experiences and outline ways to face life and power relations, even in adverse and / or extreme conditions of coercion. This means recognizing that the actors are endowed with knowledge that makes them capable of overcoming and / or adapting to adversity and positioning themselves through power relations. Through POA it is possible to inquire the premises that place power structures as fixed, in which individuals are analyzed only as static categories. The 
structures are changeable and can be rebuilt by the agency of social actors.

Rural development interventions and technological innovations instilled in social actors in rural areas are perceived through POA as endogenous processes in agriculture, which are not one-dimensional, and which do not refer only to the choices of certain technologies to the detriment of others, as in case of replacing creole seeds with commercial seeds, but to a process, in which there are pre-existing constraints and opportunities, which result in differentiated solutions, built from an interaction of knowledge of the actors (WISKERKE; PLOEG, 2004). Family farmers linked creole varieties of plants and animals to their ways of life, for different reasons. Some are motivated by productive aspects, such as productivity or cost-benefit ratio, or even by production stability. For others, aspects related to nutrition, or even organoleptic qualities and suitability for culinary and regional practices are reasons to preserve certain varieties (PEREIRA, 2017). There are still more symbolic aspects, such as maintaining certain varieties that have an affective or religious importance (OLANDA, 2015).

Considering the farmers who preserve Creole varieties, it is important to note that not everyone recognizes themselves as guardians. Some are even unaware of this concept. For many of these farmers, the function of keeping and caring for the seeds, as well as the breeds of their animals, is intrinsic to agriculture. For others, however, by identifying themselves as guardians, they differ from other farmers. This identity construction has a lot to say and highlights a series of social practices that these farmers want to highlight and value. When defining himself as a guardian farmer, the addition of this adjective comes as an act of positioning and conquering space in a medium in which fierce competition prevails. In many communities, this identity is actually a social construct, as some farmers take on the responsibility of guardian for the benefit of all. It is a socially referenced specialization, often having an association with religious aspects, which can be passed on from generation to generation (transgenerational) as a form of management.

More recently, other studies are discussing the construction of the identity of these seed custodians, as a rescue or invention of tradition, which in certain cases and in some regions, many farmers no longer had or never had the habit of saving and preserving the seeds and after introducing themselves in the context of ecological agriculture, they become adept at these practices and are entitled and recognized as guardians, for keeping alive or based on some traditions of older or even original peoples (MACHADO; SANTILLI; MAGALHÃES, 2008).

Some examples can facilitate the verification of the social agency of the actors that participate in the conservation of Creole seeds and reinforce the importance of POA in studies that investigate guardians and their social practices. First of all, it is important to mention that the guardians of Creole seeds have a list of factors that direct their choices and positions, which go beyond merely productive factors or external influences. For this reason, it is possible to counter the idea that sociotechnical impositions reach all farmers homogeneously. Many farmers have biodiverse systems, that is, agro-ecosystems in which the combination of social and organizational systems, with productive systems of different species and varieties, are important 
strategies for meeting the different uses and needs of families. There are many uses and social practices involved, and it is impossible to capture such complexity without a close look at everyday life and organizational and decision-making processes. As for the organizational processes, it is possible to exemplify in the following way, several social actors, institutions and their social mediators, are united by a common factor: the creole seeds. These actors with different interests in seeds, build networks, alliances and partnerships, seeking to ensure the maintenance and availability of seeds adapted to their local conditions. A practical result of these organizational forms are the Community Seed Banks (BSC) in Paraíba / PB. These banks are mobilized by local / regional and state actors who participate in the BSC Network of the Articulation of the Semi-arid Paraibano (ASA-PB). The state of Paraíba is a pioneer in conquering a Law (No. 7,298 / 2002) that guarantees resources for the rescue and multiplication of seeds of local varieties. The approval of this law is the result of social mobilization exercised by guardians of Creole seeds, institutions, social organizations and their mediators. And it proves that there are dynamics against the global legal dictates around seeds. These are achievements that, day by day, add up and strengthen the positions of social actors in the face of tax processes and global standards.

\section{Conceptual arrangement between Biopower and Actor Oriented Perspective (POA) in the study of Creole seeds}

For many years, discussions about power relations in agriculture focused almost exclusively on the relationships between "dominant and dominated" actors. Above all, when the eyes were focused on agrarian and land issues, as well as work in the field, under the influence of structuralist thinking. Nowadays, new questions try to extrapolate the thoughts that understand the power from its extremities, understanding that, from one pole to the other, complex power relations are established. Thus, it can be said that power relations in agriculture are conditioned by different factors, such as access to land and water, or to different inputs and technologies. Access to seeds, or even to intellectual property associated with genetic resources, has been an important factor associated with power, which places the theme of Creole varieties, usually referred to only as "Creole seeds", at the center of the discussion on the relations of power and agriculture.

Using Foucault's perspective to analytically interpret the issue of seeds and related themes, studies have focused, in the great majority, on the modernization of agriculture, such as, for example, the issues involving the difficulties and restrictions on the use and commercialization of Creole seeds and the right of farmers to agrobiodiversity, notably, the axis has been the replacement of native seeds by commercial seeds and the consequent genetic erosion in agriculture (PFRIMER; DE FREITAS COCA; JÚNIOR, 2016). From this perspective, the consequences of modernization are more evident, overshadowing significant countermovements in agriculture. Due to its scope, this perspective has been evoked to discuss the global scenario of appropriation, privatization and commercialization of seeds by large companies and the consequences of these processes on the livelihoods of farmers and their agroecosystems. 


\section{Structuralist theories conceive of rural development as something}

The combination of the perspective of Biopower with POA can facilitate the understanding of how social actors position themselves and challenge the world and its social contradictions. With Biopower it is possible to analyze the institutional powers and external forces to farmers and guardians of Creole seeds, such as the global market and socio-technical impositions, while with POA and the notion of social agency we reach the analytical dimensions that show the interdependence between the social actors, the configurations of alliances, the protagonisms and the local influences that mobilize actions in opposition and emerging social practices.

Through the POA we discuss that social actors are not inert objects of interventions and actions imposed by external actors or mediators. Many social actors in rural areas do not comply with official norms, market pressures or socio-technical standards and position themselves according to their interests and demands, reinforcing and strengthening their identities and practices of autonomy and protagonism, even participating and being the target audience of transformations socio-technical. Hence the understanding of the existence of reversibility situations that permeate social relations.

The two theoretical approaches used in this study, although distinct and of considerable complexity, contribute to the question of whether attempts to homogenize the rural space were carried out as intended by the modernization of agriculture. In this context, the discussions on the prevailing sociotechnical impositions, especially on the use of commercial seeds, and the heterogeneity in agriculture gain other interpretations in the combination of these two approaches. When combined in research of macro and microanalytical claims, they can present important elements to problematize and enrich the discussions about Creole seeds and their related themes.

It is important to mention that the notion of Biopower is not restricted to the scope of macroanalytical analyzes only, and can be used as a microanalytical approach as well. However, some studies, citing PFRIMER; DE FREITAS COCA; JÚNIOR (2013), emphasize the use of Biopower to understand the global scenario of legal and socio-technical impositions that involve seeds and the social actors that manage and conserve them, in contemporary times. As a result, issues at local levels may end up being underestimated or underestimated as analytical factors. Through POA we can see advances in this direction, mainly because it is an approach centered on social actors and on the paths they manage to trace, although they are constantly being pressured by the socio-technical regime of conventional agriculture.

It was possible to relate the concept of Biopower with the global scenario of seed privatization and commercialization. The approach of this theoretical framework contributes to understanding, mainly the control of seeds by large companies and how this control reaches and pressures farmers. These companies control the food production chain and, from political and economic pressures, they achieve legal changes that facilitate intellectual property processes such as seed patents, exercising different strategies of socio-technical impositions.

When using the POA to study the theme of Creole seeds, paying special atten- 
tion to guardians of Creole seeds and their social practices, it is possible to reflect that power in agriculture is not a static relationship in which some hold it and impose it on others, but much more a network of open and dynamic relationships, whose limits of influence have not been previously defined, that is, power is a mix of mobile and reversible relationships in which we can never, definitively, establish a limit to such actions. There is always room for the other to say no, refuse to accept the influence or even stipulate a reversible strategy to an attempt to influence him (PELLIZZARO, 2013). This mobility and reversibility in relationships are possible due to the agency power of social actors.

In a broader approach to this theoretical framework, especially with the POA analysis lens, it is possible to affirm that it is not a question of denying structures, power relations and constraints in agriculture, but rather understanding that these relations are composed of networks of social actors with different interests and specificities. When looking at the issue of Creole seeds as something in constant threat of disappearance or replacement with commercial seeds, there is a risk of being reductionist, denying numerous initiatives that are mobilizing new actions in rural areas. Apparently insignificant, when compared to the global scenario, these initiatives, when analyzed more closely, are expressive and mobilize territories, social actors, public policies and social and legal platforms.

\section{Final considerations}

This work suggests that the application of the two approaches (Biopower and POA) in the study of the theme of Creole seeds, can contribute towards complementing the other, being able to present many interpretive and analytical novelties, capable of enriching and advancing the discussions and the deepening conceptual and theoretical. Attention was drawn to the novelties that these two approaches present, which is to overcome structuralist approaches and distortions on socio-technical impositions, social mediation processes and power relations in agriculture. With Biopower and POA, we can reach the macroanalytical dimensions and the microanalytical dimensions and we move forward in this essay, albeit in a succinct way, opening up possibilities for new interpretations.

A challenge or perhaps a next step would be to think about the operationalization of these two approaches together and what methodological paths they encourage and enable in the study of Creole seeds and their related themes.

\section{References}

AGAMBEN, G. El estado de excepción. Archipiélago: Cuadernos de Crítica de la Cultura, n. 60, p. 99-109, 2004.

ALTIERI, M. A. Agrocologia: Bases científicas para uma agricultura sustentável -- 3. ed. rev. ampl. - São Paulo, Rio de Janeiro: Expressão Popular, AS-PTA, 2012. 
ARÁN, M; PEIXOTO JÚNIOR, C. A. Vulnerabilidade e vida nua: bioética e biopolítica na atualidade. Revista Saúde Pública; 41(5):849-57, 2007. Disponível em: <https://www.scielosp.org/ article/rsp/2007.v41n5/849-857/en/>. Acesso em: 10 Maio. 2019.

BRASIL. Lei no 10.711, de 05 de agosto de 2003. Dispõe sobre o Sistema Nacional de Sementes e Mudas e dá outras providências. Diário Oficial [da] República Federativa do Brasil, Poder Executivo, Brasília, DF, 06 ago. 2003, Seção 1, p. 1-4.

COTRIM, D; DAL SOGLIO, F. Análise do processo de construção do conhecimento agroecológico. In: VII Congresso Latinoamericano de Sociologia Rural. Porto de Galinhas, Alasru. Disponível em: < http://www. alasru.org/wp-content/uploads/2011/07/GT2-Analise--do-processo-de Construcao-do-Conhecimento-Agroecologico. pdf> Acesso em: 01 Maio. 2018). 2010.

CUNHA, F. L. Sementes da paixão e as políticas públicas de distribuição de sementes na Paraíba. 2013. Dissertação (Mestrado em Práticas em Desenvolvimento Sustentável) - Universidade Federal Rural do Rio de Janeiro. Seropédica, 2013.

DINIZ, F. R. A; OLIVEIRA, A. A. Foucault: do poder disciplinar ao biopoder. Scientia, v. 2, n. 3, p. 01-217, 2013. Disponível em:<www.faculdade.flucianofeijao.com.br.pdf $>$. Acesso 15 Jan. 2017.

FOUCAULT, M. A governamentalidade. Em Michael Foucault, Microfísica do poder (pp. 277293). Rio de Janeiro: Graal. Revel, J. (2005). Michael Foucault conceitos essenciais. (C.P.Filho \& N. Milanez, Trad.). São Paulo: Claraluz, 1978.

. Aula de 17 de março de 1976. . Em defesa da sociedade. São Paulo: Martins Fontes, p. 285-315, 1999.

. Em defesa da sociedade. São Paulo: Martins Fontes; 2002.

Springer, 2007.

. Security, territory, population: lectures at the Collège de France, 1977-78.

Martins Fontes, 2008.

. Nascimento da Biopolítica: curso dado no Collège de France (1977-1978). . Verdade e poder. Microfísica do poder, v. 8, p. 1-14, 1979.

GIDDENS, A. As consequências da modernidade. São Paulo, EdUnesp...... 2001.

Press, 1984.

. The constituion of society: outline of the of struturation. Cambridge, Polity

GONZÁLEZ, S. R.; PEREIRA, V. C.; DAL-SOGLIO, F. K. A perspectiva orientada ao ator em estudos sobre Desenvolvimento Rural. Perspectivas Rurales, p. 101-121, 2014. Disponível em: < https://revistas.una.ac.cr/index.php/perspectivasrurales/article/download/6386/6426>Acesso em: 20 Nov. 2018. 
GOODMAN, D., SORJ, B., and WILKINSON, J. Da lavoura às biotecnologias: agricultura e indústria no sistema internacional [online]. Rio de Janeiro: Centro Edelstein de Pesquisas Sociais, 2008. 204 p. Disponível em:<www.bvce.org > Acesso em: 19 Jul. 2018.

GLIESSMAN, S. Agroecologia: processos ecológicos em agricultura sustentável. 4-ed, Porto Alegre: Editora UFRGS, 2008.

GRAZIANO NETO, F. Questão agrária e ecologia: crítica da agricultura moderna. São Paulo: Brasiliense, 1985.

NEGRI, A; HARDT, M; ZOLO, D. Reflections on empire. Polity, 2008.

LACEY, H. A agroecologia: uma ilustração da fecundidade da pesquisa multiestratégica. estudos avançados, v. 29, n. 83, p. 175-181, 2015. Disponível em:< http://www.scielo.br/scielo. php?pid=S0103-40142015000100175\&script=sci_arttext\&tlng=es $>$ Acesso em: 9 Ago. 2016.

LIFSCHITZ, J.A. Neocomunidades: reconstruções de territórios e saberes. Estudos Históricos, Rio de Janeiro, n. 38, jul-Dez, p.67-85, 2006. Disponível em: <

http://bibliotecadigital.fgv.br/ojs/index.php/reh/article/download/2267/1406 < Acesso em: 2 Fev. 2016.

ONG, N. Sociología del desarrollo: una perspectiva centrada en el actor. México: Centro de Investigaciones y Estudios Superiores en Antropología Social, El Colegio de San Luis. 504 p. 2007.

LONG, N. E.; VAN DER PLOEG, Jan Douve. Heterogeneidade, ator e estrutura: para a reconstituiÁao do conceito de estrutura. In: Os atores do desenvolvimento rural, perspectivas teÛricas e pr• ticas socias. UFRGS, 2011. p. 21-48.

MACHADO, A. T; SANTILLI, J; MAGALHÃES, R. A agrobiodiversidade com enfoque agroecológico: implicações conceituais e jurídicas. - Brasília, DF : Embrapa Informação Tecnológica, 2008. Disponível em: https:/www.alice.cnptia.embrapa.br/bitstream/doc/555963/1/machado01. pdf> Acesso em: 2 Ago. 2017.

MONTECINOS, C. Leyes de semillas e otros pesares: los pueblos de América Latina las cuestionan e impugnam - 1. ed. - Marcos Paz: Acción por la Biodiversidade, 2014.

NEVES, D. P. Mediação Social e mediadores políticos. In: NEVES, Delma Pessanha (Org.). Desenvolvimento social e mediação política. Porto Alegre, EdUFRGS, 2008, p. 21-44.

OLANDA, R. B. Famílias guardiãs de sementes crioulas: a tradição contribuindo para a agrobiodiversidade. 2015. 155f. Tese (Doutorado). Programa de Pós-Graduação em Sistemas de Produção Agrícola Familiar. Faculdade de Agronomia Eliseu Maciel. Universidade Federal de Pelotas. Pelotas, RS. 2015. Disponível em: < http://repositorio.ufpel.edu.br:8080/handle/prefix/3038> Acesso em: 25 Ago.2017

PAULINO, J. S; GOMES, R. A. Sementes da Paixão: agroecologia e resgate da tradição. Revista de Economia e Sociologia Rural, v. 53, n. 3, p. 517-528, 2015. Disponível em:< http://www. 
scielo.br/scielo.php?pid=S0103-20032015000300517\&script $=$ sci_arttext $>$ Acesso em: 16 Fev. 2017.

PELLIZZARO, N. Michel Foucault: Um estudo do biopoder a partir do conceito de governo. PERI, v.05, n.01, p.155 - 168, 2013. Disponível em:> http://ojs.sites.ufsc.br/index.php/peri/article/viewFile/888/391< Acesso em: 3 Fev. 2017.

PEREIRA, V. C. A conservação das variedades crioulas como prática de agricultores no Rio Grande do Sul. 2017. 336f. Tese (doutorado) -- Faculdade de Ciências Econômicas, Programa de Pós-Graduação em Desenvolvimento Rural, Porto Alegre, 2017.

PFRIMER, M. H; DE FREITAS COCA, E. L; JÚNIOR, R C B. Biopolítica, movimentos sociais e recursos genéticos: o caso do PAA sementes. Boletim Goiano de Geografia, v. 36, n. 2, p. 221 239, 2016. Disponível em: < https://dialnet.unirioja.es/descarga/articulo/5613336.pdf > Acesso em: 15 Jul. 2017.

RADOMSKY, Guilherme FW. Biopolítica e desenvolvimento? Foucault e Agamben sobre Estado, governo e violência. Dados-Revista de Ciências Sociais, v. 58, n. 2, 2015. Disponível em: < https://www.redalyc.org/pdf/218/21842188008.pdf> Acesso em: 16 Jun. 2017.

SANTILLI, J. Agrobiodiversidade e direitos dos agricultores. - São Paulo: Peirópolis, 2009.

SHIVA, V. Biopirataria: a pilhagem da natureza e do conhecimento. Vozes, 2001.

. Monoculturas da mente: perspectivas da biodiversidade e da biotecnologia. Gaia, 2003.

WISKERKE, J. S. C; VAN DER PLOEG, J. D (Ed.). Seeds of transition: essays on novelty production, niches and regimes in agriculture. Uitgeverij Van Gorcum, 2004. 


\section{Michele Laffayett de Campos}

$\square$ michelelaffayett@hotmail.com

ORCiD: https://orcid.org/0000-0001-8317-0977
Submitted on: 01/10/2018

Accepted on: 02/06/2020

2020;23:e02422

\section{Fábio Kessler Dal Soglio}

$\square$ fabiods@ufrgs.br

How to cite: CAMPOS, M. L., DAL SOGLIO, F. K. Creole seeds and power relations in agriculture: Interfaces between Biopower and social agency. Ambiente $\mathbb{Q}$ Sociedade. São Paulo, v. 23, p. 1-15, 2020. 


\title{
Sementes crioulas e relações de poder na agricultura: Interfaces entre Biopoder e agência social
}

\author{
Michele Laffayett de Campos \\ Fábio Kessler Dal Soglio
}

São Paulo. Vol. 23, 2020

Artigo Original
Resumo: $O$ presente estudo versa sobre a temática das sementes crioulas a partir de duas abordagens, a do Biopoder na Biopolítica de Michel Foucault e a da Perspectiva Orientada ao Ator (POA) de Norman Long. O objetivo é relacionar o conceito de Biopoder com o cenário global de apropriação, privatização e mercantilização das sementes e discutir as contribuições e fragilidades deste referencial teórico, apresentando a POA como uma abordagem complementar para embasar essas discussões. Esse trabalho demonstrou que a aplicação das duas abordagens no estudo dessa temática, podem apresentar novidades interpretativas e analíticas. Experiências de redes de atores que mobilizam a conservação de sementes crioulas, comprovam a agência social e dinâmicas em contramão aos ditames globais. São experiências que se posicionam frente aos processos impositivos e de padrões sociotécnicos para o uso de sementes comerciais. A existência de experiências assim, justificam a escolha da POA como abordagem completar ao Biopoder.

Palavras-chave: Guardiões de Sementes Crioulas; Agroecologia; Agrobiodiversidade; Padrões sociotécnicos.

Como citar: CAMPOS, M. L., DAL SOGLIO, F. K. Sementes crioulas e relações de poder na agricultura: Interfaces entre Biopoder e agência social. Ambiente $\mathbb{\&}$ Sociedade. São Paulo, v. 23, p. 1-18, 2020.

DOI: http://dx.doi.org/10.1590/1809-4422asoc20180242r2vu2020L5AO 


\title{
Semillas criollas y relaciones de poder en la agricultura: Interfaces entre Biopoder y agencia social
}

\author{
Michele Laffayett de Campos \\ Fábio Kessler Dal Soglio
}

São Paulo. Vol. 23, 2020

Artículo original
Resumen: El presente estudio versa sobre la temática de las semillas criollas a partir de dos enfoques, la del Biopoder en la Biopolítica de Michel Foucault y la de la Perspectiva Orientada al Actor (POA) de Norman Long. El objetivo es relacionar el concepto de Biopoder con el escenario global de apropiación, privatización y mercantilización de las semillas y discutir las contribuciones y fragilidades de este referencial teórico, presentando a la POA como un enfoque complementario para basar esas discusiones. Este trabajo demostró que la aplicación de los dos enfoques en el estudio de esta temática, presenta novedades interpretativas y analíticas. Redes de actores que movilizan la conservación de semillas criollas, comprueban la agencia social y dinámicas en contra de los dictámenes globales. Son experiencias que se posicionan frente a los procesos impositivos para el uso de semillas comerciales. Así, justifican la elección de la POA como enfoque completar al Biopoder.

Palabras-clave: Guardianes de Semillas Criollas; Agroecología; la biodiversidad agrícola; Estándares sociotécnicos.

Como citar: CAMPOS, M. L., DAL SOGLIO, F. K. Semillas criollas y relaciones de poder en la agricultura: Interfaces entre Biopoder y agencia social. Ambiente $\&$ Sociedade. São Paulo, v. 23, p. 1-18, 2020. 